\section{THE COMPUTOR IN SEARCH OF OPTICAL NEURONES}

Optical Processing of Information

Edited by Donald K. Pollock, Charles J. Koester and James T. Tippett. Pp. $\mathrm{x}+286$. (Baltimore: Spartan Books, Inc.; London: Cleaver-Hume Press, 1963.) $60 \mathrm{~s}$.

PTICAL Processing of Information forms the proceed ings of a conference of the 'cross-fertilizing' type, held in October 1962 under the sponsorship of the U.S. Office of Naval Research and the American Optical Company, at Washington. The purpose was to bring modern optical devices to the knowledge of computor experts, with a view to bigger, better and faster computors. Somewhat surprisingly, the first of the nineteen speakers, Prof. H. M. Teager of the Massachusetts Institute of Technology, poured cold water on these hopes by showing very convincingly that optical elements such as fibres, lasers, photoconductors, have, at most, a very slender chance of competing with already existing electrical components, such as tunnel diodes and thin films. This did not prevent the conference from going on cheerfully for another eighteen lectures. One cannot deny that these present a great deal of stimulating and even exciting material to the inventive mind; the sort of mind for which the difficulty of ever reaching the final objective is a challenge rather than a discouragement.

The past ten years have produced two outstanding optical developments; fibre optics and lasers. Fibre bundles, one-half inch in diameter, can contain one million fibres, and can conduct a picture with about 50 lines $/ \mathrm{mm}$ over several yards, if required, over a very tortuous path. In fact, the information capacity of such a bundle is better than one logon per fibre, because more than a dozen orthogonal modes can be propagated in each (O'Brien, Snitzer, Koester of the American Optical Company). An interesting, unorthodox application of fibres is described by R. D. Hawkins in an enthusiastic article, perhaps a little too untainted by theory. Fibres are assembled into a brush with bristles of various lengths, and are made to vibrate by a complex sound. They reveal the spectrum of the sound by their amplitude pattern, a principle well known since the time of Frahm. What is novel is the idea of selecting speech sounds, even words, for recognition by putting a photographic plate in front of the fibres, exposed to the pattern which is to be recognized, which then serves as a selective mask. Somewhat more sophisticated pattern recognition principles are described in an article on the 'Perceptron' by Babcock, Friend and Heggs, but the results are somewhat disappointing in relation to the enormous gadgetry, and appear to be inferior to those obtained by W. K. Taylor (University College, London) by simpler means. André Maréchal (Paris) summarizes the interesting work of the French school on the improvement of images by optical filtering, that is to say, operating on the Fourier transform of the picture; and this is completed in an article by El-Sum, who has made important improvements in the double-diffraction method introduced by me fifteen years ago.

The rest of the contributions are mostly devoted to the production of light by lasers, and methods for its modulation. At the time of the conference, the neodymiumbarium glass laser was the great novelty, and the gallium arsenide laser was just making its first appearance. The weakness of the laser schemes is not only in their inefficiency but also in the near-impossibility of devising really fast mothods of modulation for what is essentially a high $-Q$ device.

This book will be useful to all those who would like to keep up with the development of optical art, and for anybody who wants a vivid picture of the way in which the old art of invention is carried on in the modern world.

D. GABOR

\section{EARTHQUAKES AND EARTH STRUCTURE}

\author{
Earthquakes and Earth Structure
}

By John H. Hodgson. Pp. ix + 166. (Englewood Cliffs, N.J., and London: Prentice-Hall, 1964.) $24 s$.

$\mathrm{D}^{\mathrm{R}}$ J. H. HODGSON, chief of the Division of Seismology, Dominion Observatory, Ottawa, is the famous son of a famous father-Ernest A. Hodgson. That he has written this modest book for the non-specialist should not only help to ensure that any non-specialist will henceforth be interested in seismology, but also that seismology will attract more scientists to its disciplines and more people in general to its support.

After the introduction, Earthquakes and Earth Structure is divided into four parts, the first two being approximately of equal length, and the final two each about half the length of the first. The first section is descriptive of nine well-chosen shocks, together with a selection of isolated interesting occurrences due to earthquakes. The second section is concerned with the observation of earthquakes and earth structure (seismology), the third with statistics, geography and causes, and the final one with seismic regionalization, earthquake engineering and international co-operation.

Of the earthquakes chosen for description, the earliest is the New Madrid series of 1811-12, and the most recent the swarm in Chile in 1960. This 1960 swarm in Chile began on May 21, the main shock coming about Ii min after 3 o'clock in the afternoon of the second day. The motion of this earthquake was smooth and rolling with smaller oscillations imposed on it, the maximum intensity being felt in the coastal areas from Puerto Saavedra to Isla Chiloé and along the Reloncavi fault in the Chilean Lakes region. There were thousands of lardslides and seiches in the lakes with amplitudes up to $3 \mathrm{ft}$. and in the region silty clay flowed like water. On the Isla Mocha there was a land elevation of $7 \mathrm{ft}$., so that the foundations of the dock becam? clear of water. Near Valdivia there was a depression of the land so that salt water now floods land up-river from the city. The volcano Puyehue, dormant since 1905, erupted and sent a cloud of ash and steam $20,000 \mathrm{ft}$. into the air.

The principal shock produced one of the most spectacular tsunamis on record. Some minutes after the shock the sea receded from the coast, returning about $10 \mathrm{~min}$ later with great speed and with wave heights of as much as $20 \mathrm{ft}$. The periodic retreat and advance of the sea continued throughout the afternoon. In Puerto Saavedra, debris was later found nearly 2 miles inland. This tsunami crossed the Pacific Ocean, causing coastal damage and casualties. In Japan it arrived more than $22 \mathrm{~h}$ after the time of the earthquake that caused it, attaining a height of some $12 \mathrm{ft}$., and doing much damage. 180 Japanese died as a result of this tsunami. Tremendous damage was done in Chile by the earthquake, by permanent ground displacements at the time, and by the tsunami. Many were killed and injured and the economy of the area suffered a blow from which it will take years to recover.

Considerations such as these, Dr. Hodgson asserts in his book. make it imperative to do something about the matter. Two important ways, apart from pure seismological research, are opening up in many countries throughout the world. The first is called 'seismic regionalization', and the second 'earthquake engineering'.

'Seismic regionalization' is a term first introduced by the Russian seismologists. Seismic regionalization maps are usually contoured to show maximum earthquake intensity likely to be encountered at each point on the map. Such estimates are extrapolations based on all available evidence, present geo-tectonic as well as historical-seismic. Prof. V. V. Beloussov, with the assistance 